\title{
Needle Stick Injuries among Health Care Workers of Alexandria University Hospitals
}

\author{
Manal I Hanafi ${ }^{*}$, Aida M Mohamed ${ }^{*}$, Mohamed S Kassem ${ }^{*}$, Mona Shawki ${ }^{*}$
}

\begin{abstract}
Background: Needle stick injury has been recognized as one of the occupational hazards which results in transmission of blood borne pathogens. As there was limited data on the national level about these injuries determinants of such injuries are important to investigate and to design effective prevention programs. Objective: The purpose of this study was to investigate the prevalence and circumstances of needle stick injuries among heath care personnel working at Alexandria University hospitals. Effectiveness of the existing control measures and practice of standard precautions were also assessed. Methods: A cross-sectional survey was carried out among 913 health care workers (HCW) in different clinical departments of the three teaching hospitals from January to December 2007. Data were obtained by an anonymous, self-reporting questionnaire. Health Belief Model (HBM) was used to explain standard precautions practice. Multiple linear regression was performed to predict factors associated with the practice of standard precautions. Results: Of the recruited participants, $70.6 \%(645 / 913)$ had completed the questionnaires. Nurses had the highest response rate $(92.5 \%)$. More than two thirds $(68.0 \%, n=438)$ of participating HCWs had sustained at least one needle stick injury in the last 12 months. Risk of (Needle Stick Injuries (NSIs) was significantly associated with younger age of the participants and fewer years of work experience. More specifically, of all occupational groups, nurses have the highest risk to experience needle stick injuries (62.3\%). Disposable syringes accounted for $38.4 \%$ of injuries. Most needle stick injuries (36.5\%) occurred at the patient's ward. Evaluating the kind of activity under which the needle stick injury occurred, on average $36.0 \%$ of injuries occurred during recapping of a needle especially if this practice was handily done. High risk patients (one with a history of infection with HIV, hepatitis $\mathrm{B}$, hepatitis $\mathrm{C}$, or injection drug use) were involved in $8.2 \%$ of injuries. The majority of NSIs $(73.1 \%)$ occurred at end of the shift. Most health care workers $(77.4 \%)$ were mentally distressed during their injury. Factors increase possibility of infection transmission were the procedure involving a needle placed directly in patient's vein or artery, exposure to a source patient who had evidence of blood borne infection, low immune status of the HCW (i.e., no vaccination with HBV), deep injury, and lack use of personal protective equipment. A total of 327 respondents (74.7\%) did not report the injury to an employee health service. Lack knowledge of appropriate procedure after injury was the most common cited reason for not reporting the injury. The survey revealed that use of preventive measures was inadequate. Only $10.0 \%$ of all participant workers knew new needless safety devices. The significant protective factors that decreased the frequency of needle stick injuries were using devices with safety features $(O R=0.41)$, satisfactory adherence of a health care worker to infection control guidelines $(O R=0.42)$, having training in injection safety and appropriate work practices $(\mathrm{OR}=0.14)$, comfortable room temperature during injection (OR=0.32), and availability of written protocol for prompt reporting of such injuries $(\mathrm{OR}=0.37)$. The mean standard precautions practice percent score for the health care workers was $46.32 \%$. In multiple linear regression model, knowledge score of infection transmission (adj $\beta: 0.18)$ and the work experience $(\operatorname{adj} \beta: 0.06)$ were the only significant predictors of standard precautions
\end{abstract}

\footnotetext{
* Community Medicine Department, Faculty of Medicine, Alexandria University

** Obestetric and Gyneacology Department, Faculty of Medicine, Alexandria University
} 
score. Conclusion: There is a high rate of needlestick injuries in the daily routine of Alexandria teaching hospitals with subsequent risk of infection transmission. Greater collaborative efforts are needed to prevent needlestick injuries. Such efforts are best accomplished through a comprehensive program that addresses all circumstances that contribute to the occurrence of needlestick injuries in health care workers. Critical to this effort is the elimination of needle use where safe and effective alternatives are available and the continuing development, evaluation, and use of needle devices with safety features. All such approaches must include serious initial and ongoing training efforts.

\section{INTRODUCTION}

Workplace safety is a very important aspect of occupational health practice in many countries. In industrialized and developing countries alike, there is legislation on safety and health at work with recognized codes of practice. Among health care workers (HCWs), HIV, hepatitis $\mathrm{B}$ and $\mathrm{C}$, and cytomegalovirus are recognized occupational health infections of special importance ${ }^{[1,2]}$.

According to a World Health Organization estimate, in year 2002, needle stick injuries resulted in 16,000 hepatitis $\mathrm{C}$ virus (HCV), 66,000 hepatitis $B$ virus (HBV) and 1000 human immunodeficiency virus (HIV) infections in health-care workers worldwide ${ }^{[3]}$. Previously in 1998, the Centers for Disease Control and Prevention (CDCP) estimated that approximately 800,000 US HCWs were injured by patient needles; and about 2000 of those workers were tested positive for infections of hepatitis C, 400 had got hepatitis $B$, and 35 contracted HIV[4]. Despite of the prevalence of these injuries varies from 0.11 up to 11.05 per 100 workers in Swiss hospitals ${ }^{[5]}$; there was no clear figure of occurrence of these injuries in Alexandria teaching hospitals.

In Egypt, like most of the developing countries, very few efforts have been undertaken to raise awareness of the health-care workers and hospital managers. Concrete knowledge on the transmission of blood-borne diseases in health-care facilities is very limited. Unsafe practices are very common. Additionally, there is a lack of regulation and policy to protect health workers from exposure[6]. 
Most of the time, health care workers never receive training in infection control and standard precautions although such trainings and practices are low cost solution to reducing risk of sharp injuries and have a high likelihood of being adopted[7].

Recapping, disassembly, and inappropriate disposal increase risk of NSI [7]. In developing countries, the frequency of these factors gets accentuated with high injection use at health care facilities, most of which are provided with previously used syringes ${ }^{[8]}$. Injection use is very common in Alexandria teaching hospitals. More than $30 \%$ of these injections are provided with previously used syringes. Prevalence of $\mathrm{HBV}$ and $\mathrm{HCV}$ in Egypt is high and unsafe injections transmit most of these infections. Hence, risk of NSI and associated infections is higher in Egypt as compared to those countries that have a low prevalence of $\mathrm{HBV}$ and $\mathrm{HCV}[9]$. Timely reporting of occupational exposures to an employee health service is required to ensure appropriate counseling, facilitate prophylaxis or early treatment, and establish legal prerequisites for workers' compensation. Failure to report exposures precludes interventions that could benefit the injured party, placing health care workers at unnecessary risk ${ }^{[10]}$.

Occupational Safety and Health Administration (OSHA) regulations aim at decreasing occupational exposures through use of personal protective equipment, work practice controls and education and training[11]. Moreover, The United States Centers for Disease Control and Prevention (CDC) designed regulations since 1983 to protect health care workers from risks of occupational exposure to BBP by investing employers with the responsibility of evaluating the effectiveness of existing risk control measures, and of identifying and evaluating new technologies that might 
prove to be more effective at reducing the risk of NSI occurrence ${ }^{[12]}$.

\section{AIM OF THE WORK:}

Since information is limited regarding the prevalence of needle stick injuries, the circumstances surrounding them, and the barriers to reporting them. This study was conducted to investigate the prevalence and context of needle stick injuries and behavior associated with the reporting of injuries among health care workers. An assessment of knowledge about risk perception and practice of standard precautions was also conducted. This assessment will provide essential baseline data for developing and testing low cost training interventions in standard precautions.

\section{MATERIAL AND METHODS}

\section{Study design}

A cross-sectional survey was conducted during January through December 2007.

\section{Study population \& setting}

The study population included health care personnel working at three Alexandria
University teaching hospitals. In this study, those workers (physicians, nurses, residents, attending surgeons, training physicians, interns, technicians, blood bank personnel, and supportive personnel; housekeepers, laundry, maintenance workers, and porters) who are in direct contact with the patients or with equipments used on patients and are likely to get exposed to blood borne pathogens, were included.

\section{Sample size}

Health care in the three teaching hospitals is provided by 6087 workers (Statistical Administrative Records of University Hospitals, 2007). The total number of health care workers to be selected was estimated using the following equation: $n=\left(Z^{2} \times p X q\right) / D^{2}$. Since the actual prevalence of the condition under the study is unknown, the probability of its occurrence was estimated to be equal to that of its non-occurrence $(p=q=0.50)$ and a value of 0.20 was chosen as the 
acceptable limit of precision (D). Based on these assumptions, the sample size is estimated to be 913 health care workers. From each of the above occupational groups, Nurses ( $n=401)$, physicians $(n=67)$, residents, attending surgeons, training physicians, interns $(n=74)$, technicians and blood bank personnel $(n=153)$, and supportive personnel $(n=218)$. Those were proportionally allocated based on each job category in different clinical departments $(n=21)$.

\section{Data collection tool}

An anonymous self-administered questionnaire was distributed to the health care workers at their work place. The questionnaire was prepared in Arabic language. The purpose, procedure, risks, and benefits of the study were explained to the respondents and a verbal informed consent was obtained. Ethics Review Committee at Alexandria Faculty of Medicine reviewed and approved the proposal. The survey tool was pre-tested on a random sample of 55 participants to ensure practicability, validity, and interpretation of responses. The reliability of the questionnaire was assessed using Cronbach's alpha (0.812).

Questionnaire included information on socio-demographics, professional qualifications and total number of years since start of practice. We also inquired about needle stick injuries during the past twelve months and circumstances surrounding the latest injury. Self-reporting effectiveness of the control measures was also assessed.

Health Belief Model (HBM) was used in the questionnaire ${ }^{[13]}$. In HBM, knowledge influences perception about disease susceptibility and disease severity. Both of these determine perceived disease threat which, in turn, influences behavior. Behavior is also determined by perceived self efficacy (confidence in one's ability to perform certain activity), cues to action and barriers and benefits (Figure 1). 
Questionnaire of the present work (measured as $0=$ always to $3=$ never) and measured knowledge about infection appropriate waste handling (measured as 0 transmission following needle stick injury using one item 'Can injury by needles at work place transmit hepatitis B, C or HIV?' $($ Yes $=1$, No $=0)$. Perceived susceptibility to acquiring blood borne pathogens was assessed using one item "how much risk of acquiring a BBP is involved in your work", on a scale of 1 (being none) to 5 (being very high). Perceived severity of consequences of needle stick injury was assessed by one item "what can happen if you get a needle stick" with responses of nothing and acquisition of BBP and others. Behaviors (universal precaution practices) included information on vaccination against hepatitis B (yes/no), wearing gloves while performing medical and surgical procedures (measured on a scale of $0=$ never to always $=3$ ), wearing gowns for procedures where possibility of blood/ body fluid splash (measured on a scale of $0=$ $=$ always to 3 = never). Perceived benefits were assessed using one item 'Do you believe that universal precautions practice protect against blood borne infections?'. Perceived barriers were assessed using two items.) Unavailability of protective equipment and Lack of training in universal precautions' (Yes $=1$, No $=0)$, Cue to action was assessed using one item Are you exposed to factors that prompt action should be taken (Yes $=1$, No $=0$ ), and lastly perceived self-efficiency was assessed using one item 'Are you confident in your ability to successfully practice safe universal precautions at your workplace (not confident $=0$, completely confident $=2$ )

Knowledge and standard precautions practice percent score was calculated using the following formula total score/Maximum possible score $\mathrm{X} 100^{\prime}$ never to always $=3$ ) recapping of needle 


\section{Statistical analysis}

Data were entered in Epi-Info version 6.04 and analysis was performed using SPSS version 13.0. Data gathered from the cross sectional survey were analyzed using the case control approach. Means $( \pm S D$ ) were computed for continuous and proportions for categorical variables. Odds ratio (OR) and the corresponding 95\% confidence interval $(\mathrm{Cl})$ were computed.

High risk injured workers $(n=187)$ were identified by 12 statements addressing factors that increase possibility of infection transmission. Each statement was scored zero for no and one for yes, then total score was computed. Those workers who had total score above the median were considered to get high risk injury. Multiple linear regression analysis was performed to assess the relationship of infection transmission knowledge score, precaution knowledge score, perceived risk at work place, perceived severity of disease due to NSI at work place, age, work experience, respondent qualification with the practice of universal precautions score. Those variables that were significant at $P<0.05$ were selected for multivariable model. The assumptions model fitness was assessed using residual plots. Alpha was set at the $5 \%$ level.

\section{RESULTS}

\section{Distribution of job categories}

The total number of full time HCWs employed by the three participating hospitals was 6087. Due to various absences through sick leave, annual leave, maternally leave, business leave, and study leave, there were 913 (15.0\%) health care workers (HCWs) selected for questionnaire distribution.

Of the recruited participants, $70.6 \%$ (645/913) had completed the questionnaires (Table 1). Nurses had the highest response rate $(92.5 \%)$, followed in order by physicians (83.6\%), residents, attending surgeons, training physicians, interns, (74.3\%), then technicians and 
blood bank personnel (57.5\%). The occurrence of NSls (OR=1.8, 95\% supportive personnel had the lowest $\mathrm{Cl}=0.64-2.7)$.

response rate (34.4\%). Male HCWs Circumstances of NSIs

accounted for $31.9 \%$ of the sample. The

age of the participating HCWs ranged from

17 years to 60 years, with a mean age of

30.8 years (SD 8.6 years).

\section{Prevalence of NSIs}

More than two-thirds $(68.0 \%, \mathrm{n}=438)$ of participant HCWs had sustained at least one needlestick injury in the last 12 months. For the workers who reported that they had NSI, 33.0\% had one, $18.0 \%$ had two, $12.0 \%$ had three, and $5.0 \%$ had more than three NSIs (Figure 2).

Table 2 shows that health care workers aged forty years and more $(16.4 \%$ for age group $40-<50$ years, and $11.6 \%$ for the age group 50-60 years) and those with 5 years of work experience or more (26.1\%) were significantly less likely to be injured $(\mathrm{OR}=0.32, \quad 0.28$ and 0.34 , respectively). However, gender had no effect on the dialysis units $(12.6 \%)$, operating rooms (10.5\%), emergency rooms (8.9\%), 
outpatient settings (6.4\%), delivery rooms (5.2\%), and laboratories (4.1\%). Evaluating the kind of activity under which the needlestick injury occurred, on average $36.0 \%$ of injuries occurred during recapping of a needle especially if this practice was handily done. High percentage of needlestick injuries (28.3\%) also occurred during disposal of the used device. High risk patients (one with a history of infection with HIV, hepatitis B, hepatitis $\mathrm{C}$, or injection drug use) were involved in $8.7 \%$ of injuries. The majority of NSIs $(73.1 \%)$ occurred at end of the shift. Most health care workers $(77.4 \%)$ were mentally distressed during their injury.

Risk of infection after a needle stick injury

Table 4 shows that a health care worker's risk of infection was 9.07 times higher when the procedure involving a needle placed directly in patient's vein or artery, and this was significant $(\mathrm{p}=0.013)$. Exposure to a source patient who had evidence of blood borne infection was a risk factor that significantly increased the odds of infection transmission $(O R=12.36$, $p=0.003)$. Just less than a fifth, $18.3 \%$, of staff surveyed reported to be either unprotected or be unaware of their serological status. Immune status of HCW (no vaccination with $\mathrm{HBV}$ ) significantly increased the odds of infection transmission $(\mathrm{OR}=6.35, \mathrm{p}=0.000)$. Health care workers with deep injuries were at risk 6.60 for infection transmission than those with superficial injury as indicated by $\mathrm{OR}=6.60, \mathrm{p}=0.000$. Moreover, HCWs who did not wear personal protective equipment were significantly at risk of infection transmission than those who weren't $(\mathrm{OR}=5.20, p=0.001)$. However, device nature, duration of potential contact, body part injured, time interval between injury and wound cleansing, availability and use of prophylactic medication, and follow up testing for the exposed workers were not 
significantly affect the occurrence of infection transmission.

\section{Rate of underreporting}

A total of 327 respondents $(74.7 \%)$ did not report the injury to an employee health service. Physicians are much less likely to report a needle stick injury than other healthcare professionals. Of 327 respondents, $22.6 \%$ lacked knowledge of appropriate procedure after injury, 20.5\% judged of sufficient HBV vaccination, $19.9 \%$ had perception of low risk not a serious exposure, $16.5 \%$ had time constraints, $14.7 \%$ were likelihood of selfcare, and $5.8 \%$ feared of punitive employer response as the possible reason for not reporting the injury (Figure 3).

\section{Self-reporting effectiveness of existing control measures}

Only $10.0 \%$ of all participant workers knew new needless safety devices. Table 5 reveals that devices with safety features decreased the frequency of needlestick injuries as indicated by $\mathrm{OR}=0.41,95 \%$ $\mathrm{Cl}=0.21-0.73$. Also, satisfactory adherence of a health care worker to infection control guidelines was a protective factor that prevent needlestick injuries $(\mathrm{OR}=0.42,95 \%$ $\mathrm{Cl}=0.26-0.71) . \quad$ A significantly higher percentage of health care workers $(27.0 \%)$ did not experience NSIs because of having training in injection safety and appropriate work practices $(\mathrm{OR}=0.14,95 \% \mathrm{Cl}=0.03$ 0.40). Moreover, comfortable room temperature was a protective factor that decreased the odds of needlestick injuries among health care workers (OR=0.32, 95\% $\mathrm{Cl}=0.06-0.67) . \quad$ A significantly higher percentage of those workers who did not experience NSIs (38.6\%) reported available written protocol for prompt reporting of such injuries as compared to those experienced NSIs (9.6\%), (OR=0.37, $95 \% \mathrm{Cl}=0.02-0.57)$. However, availability of personal protective equipment, characteristics of the disposable containers regarding location, rigidity and box design, full immunization against hepatitis $B$, double gloving practice, organized shift 
schedule, sufficient staff number, work environment characteristics, as well as periodic in-service health monitoring were factors that not significantly affect the risk of NSls.

Standard precautions practice \& its predictors

Knowledge percent score of health care workers about the risks associated with needle-stick injuries ranged from 30 to $82 \%$ with a mean percent score of $58.7 \%$. Standard precautions practice percent score for the health care workers ranged from $27 \%$ to $78 \%$ with a mean percent score of $46.32 \%$. In multiple linear regression model, knowledge score of infection transmission (adjusted $\beta$ : 0.18, $95 \% \mathrm{Cl}=0.06-0.29)$ and the work experience (adjusted $\beta$ : 0.06 95\% Cl: 0.020.09 ) were the only significant predictors of universal precautions score. Hence, the practice of universal precautions depends on knowledge of infection transmission following a needlestick injury and work experience of the health care worker. Final model explained $9.3 \%$ variation in the safety precaution score (Table 6). Residual analysis using the assumptions of normality, linearity, and constant variance revealed that the model fits well.

\section{DISCUSSION}

Because little is known about the prevalence and circumstances of needlestick injuries among health care workers in Alexandria teaching hospitals since it has been estimated that most of these injuries go unreported, this study contributed to the understanding of the risks of exposure to such injuries among health care workers in hospital settings. Such information will contribute significantly to an understanding not only the risk for such injuries but also the development of effective intervention strategies.

Needlestick injuries pose a significant occupational risk for health care workers of Alexandria teaching hospitals. More than 
two-thirds (68.0\%) of participant HCWs had sustained at least one needlestick injury in the last 12 months preceding the study.

In the developing countries, on average 2 million NSIs are projected yearly. This is probably a low estimate, because of the lack of surveillance systems and underreporting of injuries ${ }^{[8]}$. Lower prevalence of needle stick injuries among Malaysian health care workers in two teaching hospitals were reported to be $31.6 \%$ and $52.9 \%$, respectively ${ }^{[14]}$.

Data from injection safety surveys conducted by the WHO and others show on average: four NSIs per worker per year in the African, Eastern Mediterranean, and Asian populations ${ }^{[8]}$. In Vietnam, $38 \%$ of physicians and $66 \%$ of nurses reported sustaining a sharp stick injury in the previous nine months[15]. In South Africa, $91 \%$ of junior doctors reported sustaining a needlestick injury in the previous 12 months, and $55 \%$ of these injuries came from source patients who were HIVpositive ${ }^{[16]}$.

The present study provided descriptive epidemiological evidence of how such injuries occur, including under what circumstances, with what devices and during what types of procedures. The picture that emerges reflects a continuum of risk opportunities throughout the lifecycle of the device use involving interactions among patients, workers, devices, and the environment.

Overall, the epidemiological patterns of reported NSI were consistent with other authors' reviews ${ }^{[17-19]}$. Physicians mostly do not provide injections as nurses do and hence their risk of injury exposure is lower. The housekeepers clean and collect waste without protective equipment and hence are at the high risk of injury exposure.

Concerning device-specific needlestick injury, syringe needles, were associated with $38.4 \%$ of all NSI experienced by studied HCWs. This finding was consistent 
with data presented by Ippolito et al. HCW to patient ratio may be higher in more 1997[20], where hollow-bore needles intensive units than in a low intensive unit. accounted for $38.5 \%$ of percutaneous So that clinical manipulations may be injuries. Some prevention strategies need to be developed, including important and cost effective behavioral changes in HCWs. Implementing engineering control, for example, by providing safer needle devices to all HCWs has constantly been suggested (Sohn, 2004)[21]. It has also been suggested that implementing sharps containers at desirable spots will shorten the distance that a used needle being held has to travel (Shiao, 1997) ${ }^{[22] .}$

More NSIs occurred at geographic locations that were, surprisingly, less intensive such as patient rooms than more intensive in activity. This phenomenon may be associated with HCWs who, perhaps, were being more cautious while working in higher intensive units where highly invasive procedures are performed. Alternatively, this result may be associated with a workload related phenomenon where the performed with more staff and hence a more controlled environment. While HCWs in the less intensive units may have responsibilities for more patients which may then cause staff to rush[23].

In contrary to finding of the present work, $38 \%$ of percutaneous injuries among Taiwan HCWs occur during use, when a needle being manipulated in a patient becomes accidentally dislodged ${ }^{[24]}$. Recapping of needles was prevalent in Alexandria HCWs. This survey revealed that $36.0 \%$ of injuries occurred while recapping a used needle. Inspite that recapping was prohibited by the Occupation Safety and Health Administration (OSHA); it continues to be an identified cause of injury[25].

High risk patients (one with a history of infection with HIV, hepatitis $B$, hepatitis $C$, or injection drug use) were involved in 
$8.2 \%$ of injuries. These are highly disease, and of those that do, the majority transmissible pathogen and with the high do not result in the transmission of prevalence of NSI with hollow-bore infection. Nevertheless, needle stick needles. This is especially a concern injuries may expose workers to blood considering hollow-bore needles are borne pathogens such as human effective in delivering large amounts of immunodeficiency virus (HIV), hepatitis B blood and body fluids[26].

Of the blood borne pathogens, HBV is preventable. Teaching hospitals in Alexandria have not made the provision of HBV vaccination a requirement of employment at a health care facility. Just less than a fifth, $18.9 \%$, of staff surveyed reported to be either unprotected or be unaware of their serological status. This means that those health care facilities surveyed have allowed this proportion of staff to remain a risk to themselves or to their patient population. A vaccination program for staff, including clinical and non-clinical has been recommended by the Centers for Disease Control (CDC) since 1983[27]. Fortunately, not all needle stick injuries result in exposure to an infectious virus, and/or hepatitis $C$ virus ${ }^{[28]}$. A health care worker's risk of infection in the present work depends on several factors, such as the procedure involving a needle placed directly in patient's vein or artery, exposure to a source patient who had evidence of blood borne infection, immune status of the $\mathrm{HCW}$, the severity of the needle stick injury, and the availability personal protective equipment. Prospective studies of health care workers exposed to HCV through a needle-stick or other percutaneous injury have found that the incidence of anti-HCV sero-conversion averages $1.8 \%$ (range $0 \%-7 \%$ ) per injury[29]. A data combined from more than 20 prospective studies worldwide of health care workers exposed to HIV infected 
blood through percutaneous injury revealed an average transmission rate of $0.3 \%$ per injury[30].

Understanding the scope of the problem requires recognizing the underreporting problem. Of the 438 health care workers with a history of needle stick injuries, 327 respondents $(74.7 \%)$ did not report the injury to an employee health service. It is believed that only one out of four needle stick injuries are reported in Alexandria teaching hospitals. The underreporting of needle stick injuries is also a serious problem in other researches, thus $40-80 \%$ of all injuries go unreported[31].

The present study identified common reasons for non-reporting of needle stick injuries that warrant attention. In the absence of access to post-exposure prophylaxis, there is little perceived benefit to reporting occupational exposures, especially when reporting can result in punishment, blame, or job loss. When onsite evaluation and treatment is not available, workers may not be able to receive antiretroviral medication, if needed, on a timely basis. In addition health workers commonly minimize the risk of the exposure. Barriers to reporting should be appropriately identified and eliminated in order to ensure appropriate care and treatment of health workers to prevent infection as a result of exposure.

Reporting the injury to an employee health service enables counseling regarding the risk of exposure and prevention of secondary transmission, including possible transmission to patients, and may alleviate associated anxiety. It also allows medical evaluation, including testing and, if warranted, antiretroviral therapy or administration of the HBV vaccine containing hepatitis $B$ immune globulin. Antiretroviral therapy administered within 24 to 36 hours after exposure has been associated with an $81 \%$ reduction in HIV infection. Although no post-exposure prophylaxis is available for $\mathrm{HCV}$, testing 
with HCV RNA can identify HCV infection at an early stage, during which treatment is highly effective in preventing chronicity. Furthermore, reporting of needle stick injuries may be required to establish the causal relationship of the exposure and subsequent complications (e.g., chronic infection or inability to practice medicine). Although legal requirements vary, failure to report an occupational exposure may lead to the denial of subsequent claims ${ }^{[32]}$.

Health workers in the present study were not educated in occupational blood borne hazards as indicated by low percent score of infection transmission following needle stick injuries. Accurate information about the risk of blood borne transmission from occupational exposure to needle sticks is necessary and should include information about the most effective measures to control exposure and infection.

This study assessed the effectiveness of existing control measures. The survey revealed that use of preventive measures was inadequate. Although an increasing number and variety of needle devices with safety features are now available. Only $10.0 \%$ of workers knew about new needleless safety devices. In accordance to finding of the present research, needleless or protected needle IV systems have decreased the incidence of needle-stick injuries by $62 \%$ $88 \%$. Health care worker can help the employer in the selection and evaluation of such devices $^{[33]}$.

A satisfactory adherence of HCWs to infection control guidelines was a protective factor to prevent NSIs. Noncompliance to a safe work practice is determined by a range of factors including lack of knowledge, interference with work skills, risk perception, conflict of interest, not wanting to offend patients, lack of equipment, and time, uncomfortable personal protective equipment, inconvenience, work stress, and perceiving a weak organizational commitment to safety climate ${ }^{[32]}$.

Certain working conditions increase the risk of needle stick injury. Those were staff reductions where health care workers 
assume additional duties or are rushed; practice among health care workers. This is difficult patient care situations; and working at night with reduced lighting ${ }^{[34]}$. However, the present work found that these factors conditions had no effect on the occurrence of NSIs.

Standard Precautions represents a system of barrier precautions to be used by all personnel for contact with blood, all body fluids, secretions, excretions, non intact skin, and mucous membranes. It applies to all patients receiving care in hospitals, regardless of their diagnosis or presumed infection status. These precautions are the "standard of care." Standard Precautions focuse on reducing the risk of transmission of microorganisms. This system embodies the concepts of Standard Precautions (Blood and Body Fluid Precautions designed to reduce the risk of transmission of blood borne pathogens) and Body Substances Isolation (designed to reduce the risk of transmission of pathogens from moist body substances) ${ }^{[35]}$.

The Health Belief Model (HBM) is used to explain and predict standard precautions done by focusing on the attitudes and beliefs of individuals. In the present survey, the mean percent score of standard precautions practice was $46.32 \%$. In developed countries, standard precautions use rate in teaching hospitals is considerably higher as compared to the present setting. In the United States, a study conducted in two teaching hospitals in Minneapolis reported that gloves were observed to be used when appropriate $67.2 \%$ of the time, followed by goggles (50.7\%), masks (16.0\%), gowns (15.3\%). Needles were recapped in $34.4 \%$ of cases $^{[36]}$. Another study reported a varied compliance rate regarding standard precautions among hospital physicians in United States: glove use: $94 \%$; disposal of sharps: $92 \%$, wearing protective clothing: 55\%; not recapping needles: $56 \%{ }^{[37]}$. Summarizing results from these comparisons suggest that knowledge of infection transmission following NSIs and work experience play important roles in prediction of standard precautions practice at university hospitals of Alexandria. 
Limitations of the present study should be noted. Because all information was selfreported, misclassification is possible, although the anonymous nature of the survey would be expected to facilitate accurate reporting. Also, this work lacked data on outcomes, including results of serologic testing for HIV, hepatitis B or C infection among HCWs who sought care for their injuries. Although needle stick injuries are the most common type of exposure, yet other percutaneous and splash exposures represent additional hazards to the HCWs; this work did not collect data on these exposures.

\section{Areas for Further Research}

As with any emerging public health problem, there are several important areas in which our knowledge about needle stick injuries and their prevention can be improved.

Studies are recommended to determine the adverse outcomes of these injuries, including infectious, psychological, and financial. Because most of the medical devices are in the first generation stage, ongoing review of current devices and options will be necessary. Research will continue to improve the safety features of devices. Evaluation studies to provide improved information on what does and does not work will similarly continue to improve the effectiveness of comprehensive safety programs. Because training for employers and health care workers is a vital part of a comprehensive prevention program, model training curriculums need to be developed and evaluated at regular intervals.

\section{CONCLUSION}

While the science base on needle stick injuries continues to grow, completed research indicates that such injuries are an important and continuing cause of exposure to serious and sometimes fatal infections among health care workers. Greater collaborative efforts by all stakeholders are needed to prevent needle stick injuries and the consequences that can result. Such efforts are best accomplished through a comprehensive program that addresses institutional, behavioral, and device-related factors that contribute to the occurrence of 
needle stick injuries in health care workers. Critical to this effort is the elimination of needle use where safe and effective alternatives are available and the continuing development, evaluation, and use of needle devices with safety features. All such approaches must include serious initial and ongoing training efforts. Accurately tracking needle stick injuries is critical. Establishment of surveillance that could be used to identify potential risk factors associated with needle stick injuries, such as high-risk occupations, settings, or procedures, and detects the emergence of new problems. Surveillance systems could be used also to track whether interventions put into place significantly help reduce injuries.

\section{RECOMMENDTIONS}

1. Avoid use of sharp or needled devices whenever possible

2. Improve the design of sharp equipment to reduce the likelihood of accidental injury

3. Locate disposal containers close to work sites to reduce the necessity of transporting .
4. Uncapped devices, avoid over filling disposal containers and use containers designed to exclude hands and fingers

5. Modify work practices to reduce risks. For example: avoid recapping used syringes, or use one-handed recapping techniques with assistive devices, set up instrument trays with uniform orientation of all sharps, segregate sharp from non-sharp equipment, separate used from unused sharps, and use forceps to dispose of contaminated devices

6. Improve and standardize reporting of sharps injuries to facilitate surveillance

7. If HCW are potentially exposed to blood borne pathogens as a result of NSI, implement post-exposure follow up of the injured $\mathrm{HCW}$. If the viral status of the donor patient is unknown, implement followup of the patient.

8. Post-exposure infection rates may be reduced by prompt prophylactic anti-viral treatment and this should be considered in the development of risk reduction and management plans. 
Items

Constructs

Knowledge (1 item)

1 Can injury by needles at work place trams mitt hepatitis B, C or HIV? (Yes =1, No = 0)

Perceived susceptibility of acquiring infection at workplace (1 item)

How much risk of acquiring hepatitis $\mathrm{B}, \mathrm{C}$, and/or HIV is involved in your work setting ( 1 = None to 5 = Very high)

Perceived severity of disease after NSI

1 What can happen if accidentally any of Health Care Worker got needle stick injury? $(1=$ infection with any of blood borne pathogen, $0=$ Nothing)

Behaviors- standard precautions components (5 items)

1 Completed HBV vaccination ( $Y e s=1, \mathrm{No}=0$ )

2 Wear gloves in procedure where possibility of blood/body fluid exposure (Never $=0$ to Always $=3$ )

3 Wear gown for procedures where possibility of blood/body fluid splash (Never $=0$ to Always $=3$ )

$4 \quad$ Needle recap after use (Never $=0$ to Always $=3$ )

5 Appropriate waste handling (Never $=0$ to Always $=3$ )

Perceived benefits (1 item)

1 Do you believe that universal precautions practice protect against blood borne infections? (strongly disagree $=0$, strongly agree $=4$ )

Perceived barriers (2 items)

1 Unavailability of protective equipment (Yes $=1$, No $=0$ )

2 Lack of training in universal precautions ( $\mathrm{Yes}=1$, No $=0$ )

Cue to action (1 item)

1 Are you exposed to factors that prompt action* should be taken (Yes $=1$, No $=0$ )

Perceived self-efficiency (1 item)

1 Are you confident in your ability to successfully practice safe universal precautions at your workplace (not confident $=0$, completely confident $=2$ )

*Mass media campaign, advice from others, reminder pamphlet from the administration, illness of a friend or workmate, newspaper or magazine article.

Figure1: Health Belief Model constructs used in questionnaire for study of needle stick injuries among health care workers in Alexandria teaching hospitals

TABLE 1: JOB CATEGORY BY RESPONSE RATE, GENDER, AND AGE OF Health CARE Workers.

\begin{tabular}{|c|c|c|c|c|}
\hline JOB CATEGORY & $\begin{array}{l}\text { NO. RESPONDENT / } \\
\text { NO. } \\
\text { QUESTIONNAIRE }\end{array}$ & $\begin{array}{c}\% \\
\text { RESPONDED }\end{array}$ & $\begin{array}{c}\% \\
\text { MALE }\end{array}$ & $\begin{array}{c}\text { AVERAGE AGE } \\
(M E A N \pm S D)\end{array}$ \\
\hline $\begin{array}{l}\text { Nurses } \\
\text { Physician } \\
\text { Residents, attending } \\
\text { surgeons, training } \\
\text { physicians, interns } \\
\text { Technicians, blood bank } \\
\text { personnel } \\
\text { Supportive personnel }\end{array}$ & $\begin{array}{c}371 / 401 \\
56 / 67 \\
55 / 74 \\
88 / 153 \\
75 / 218\end{array}$ & $\begin{array}{l}92.5 \\
83.6 \\
74.3 \\
57.5 \\
\\
34.4\end{array}$ & $\begin{array}{c}0.0 \\
26.8 \\
23.0 \\
80.7 \\
50.0\end{array}$ & $\begin{array}{c}27.8 \pm 6.6 \\
32.0 \pm 7.4 \\
43.8 \pm 11.2 \\
34.9 \pm 7.2 \\
39.4 \pm 8.7\end{array}$ \\
\hline Total & $645 / 913$ & 70.6 & 31.9 & $30.8 \pm 8.6$ \\
\hline
\end{tabular}




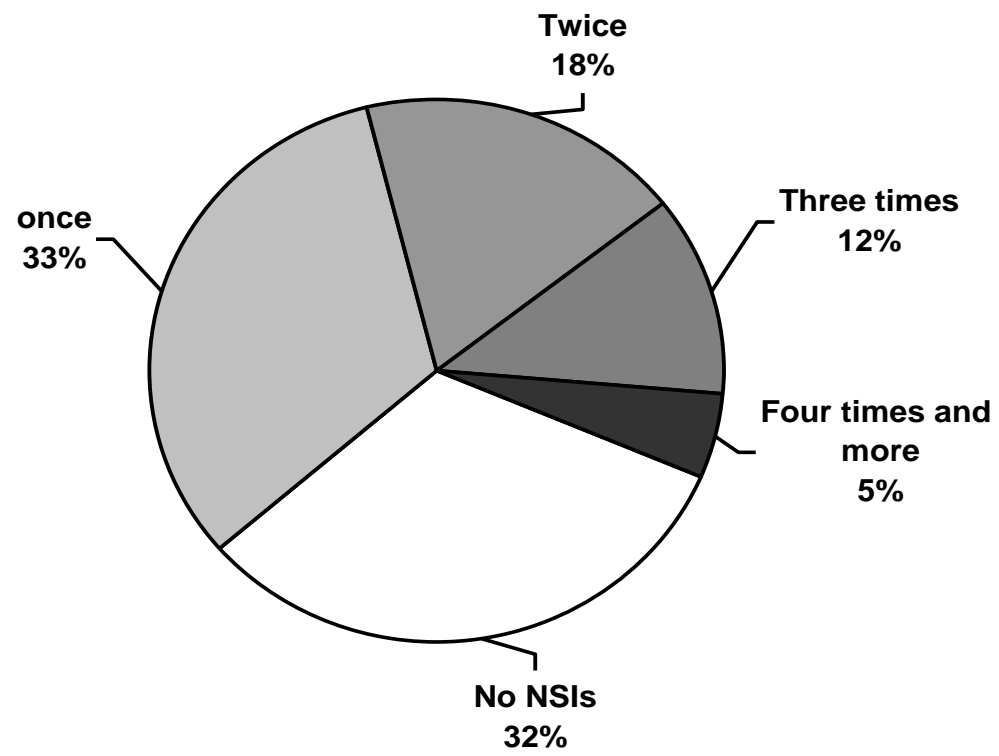

Figure 2: Prevalence of needle stick injuries (NSIs) among health care workers $(n=645)$ in teaching hospitals of Alexandria

Table 2: Personal Characteristics of Health Care Workers Experiencing NSIS AND THOSE NOT EXPOSED TO SUCH INJURIES.

\begin{tabular}{|c|c|c|c|c|c|c|}
\hline \multirow{2}{*}{$\begin{array}{c}\text { PERSONAL } \\
\text { CHARACTERISTICS }\end{array}$} & \multicolumn{2}{|c|}{$\begin{array}{c}\text { NSIS } \\
(\mathrm{N}=438)\end{array}$} & \multicolumn{2}{|c|}{$\begin{array}{c}\text { NO NSIS } \\
(\mathrm{N}=\mathbf{2 0 7})\end{array}$} & \multirow[t]{2}{*}{ OR } & \multirow[t]{2}{*}{$95 \% \mathrm{Cl}$} \\
\hline & No. & $\%$ & No. & $\%$ & & \\
\hline \multicolumn{7}{|l|}{ Age group (years): } \\
\hline $20-$ & 138 & 31.5 & 46 & 22.2 & 0.74 & $0.39-1.84$ \\
\hline $30-$ & 112 & 25.6 & 50 & 24.2 & 0.96 & $0.45-2.74$ \\
\hline $40-$ & 36 & 8.2 & 34 & 16.4 & 0.32 & $0.02-0.59$ \\
\hline $50-60$ & 10 & 2.3 & 24 & 11.6 & 0.28 & $0.01-0.51$ \\
\hline \\
\hline Males & 143 & 32.7 & 63 & 30.2 & 1 & ---- \\
\hline Females & 295 & 67.3 & 144 & 69.8 & 1.8 & $0.64-2.7$ \\
\hline \multicolumn{7}{|l|}{ Work experience } \\
\hline (years) & 219 & 40.0 & 67 & 32.4 & 1 & ----- \\
\hline$<1$ & 162 & 47.0 & 86 & 41.5 & 0.76 & $0.37-1.85$ \\
\hline$\geq 5$ & 57 & 13.0 & 54 & 26.1 & 0.34 & $0.01-0.73$ \\
\hline
\end{tabular}


Table 3: Circumstances of most recent Needle Stick InJuries among Health Care WORKERS ( $\mathrm{N}=438$ ) IN TEACHING HOSPITALS.

\begin{tabular}{|c|c|c|}
\hline CIRCUMSTANCES & NO. & $\%$ \\
\hline $\begin{array}{l}\text { Occupational groups } \\
\text { Nurses } \\
\text { Physicians } \\
\text { Residents \& Attending surgeons, training physician, interns } \\
\text { Technicians, blood bank personnel } \\
\text { Supportive personnel (Housekeepers, laundry, maintenance workers, } \\
\text { and porters) }\end{array}$ & $\begin{array}{l}273 \\
48 \\
47 \\
8 \\
62\end{array}$ & $\begin{array}{l}62.3 \\
11.0 \\
10.7 \\
1.8 \\
14.2\end{array}$ \\
\hline $\begin{array}{l}\text { Device involved } \\
\text { Syringe needle (pre-filled-disposable) } \\
\text { Winged (butter-fly needle) } \\
\text { Suture needle } \\
\text { Hypodermic needle attached to disposable syringe } \\
\text { IV catheter stylet } \\
\text { Blood collection (needle holder or vacuum tube) } \\
\text { Lancets used for skin prick }\end{array}$ & $\begin{array}{l}168 \\
59 \\
102 \\
15 \\
34 \\
26 \\
33 \\
\end{array}$ & $\begin{array}{l}38.4 \\
13.5 \\
23.3 \\
3.5 \\
7.8 \\
5.9 \\
7.6\end{array}$ \\
\hline $\begin{array}{l}\text { Location of occurrence (medical speciality area) } \\
\text { Patients' wards (in-patient units) } \\
\text { Intensive care unit (ICU) } \\
\text { Dialysis unit } \\
\text { Operating room / Theatre } \\
\text { Emergency room/Department } \\
\text { Out-patient settings } \\
\text { Delivery room } \\
\text { Laboratories }\end{array}$ & $\begin{array}{l}160 \\
69 \\
55 \\
46 \\
39 \\
28 \\
23 \\
18\end{array}$ & $\begin{array}{l}36.5 \\
15.8 \\
12.6 \\
10.5 \\
8.9 \\
6.4 \\
5.2 \\
4.1\end{array}$ \\
\hline $\begin{array}{l}\text { Activity during NSIs occurrence } \\
\text { During use of the device } \\
\text { Before use of the device } \\
\text { Recapping or disassembly of a needle } \\
\text { After use and before disposal } \\
\text { During disposal (appropriate) } \\
\text { Inappropriate disposal of the used device (Container too full-Wrong } \\
\text { type) }\end{array}$ & $\begin{array}{l}38 \\
46 \\
158 \\
49 \\
23 \\
124\end{array}$ & $\begin{array}{l}8.7 \\
10.5 \\
36.0 \\
11.2 \\
5.3 \\
28.3\end{array}$ \\
\hline $\begin{array}{l}\text { Work practices } \\
\text { Handed recapping } \\
\text { Collision with health care worker or sharp } \\
\text { Patient moved and jarred device } \\
\text { Manual tissue retraction } \\
\text { Unsafe collection and disposal of sharps waste } \\
\text { Handle/pass equipment } \\
\text { Transferring body fluids between containers }\end{array}$ & $\begin{array}{l}148 \\
75 \\
42 \\
23 \\
72 \\
40 \\
38 \\
\end{array}$ & $\begin{array}{l}33.8 \\
17.1 \\
9.6 \\
5.3 \\
16.4 \\
9.1 \\
8.7 \\
\end{array}$ \\
\hline $\begin{array}{l}\text { Involvement of high-risk patient } \\
\text { No } \\
\text { Yes } \\
\text { Unsure/Not specified }\end{array}$ & $\begin{array}{l}211 \\
36 \\
191 \\
\end{array}$ & $\begin{array}{l}48.2 \\
8.2 \\
43.6 \\
\end{array}$ \\
\hline $\begin{array}{l}\text { Time of NSI occurrence } \\
\text { Shift begin } \\
\text { Shift end }\end{array}$ & $\begin{array}{l}118 \\
320\end{array}$ & $\begin{array}{l}26.9 \\
73.1\end{array}$ \\
\hline $\begin{array}{l}\text { Health care worker health status } \\
\text { Normal } \\
\text { Chronic illness } \\
\text { Mental distress }\end{array}$ & $\begin{array}{l}47 \\
52 \\
339\end{array}$ & $\begin{array}{l}10.7 \\
11.9 \\
77.4\end{array}$ \\
\hline
\end{tabular}

* High-risk patient (one with a history of infection with HIV, hepatitis B or hepatitis C or injection-drug use). 
Table 4: Factors Increasing Possibility of Infection transmission among Health Care Workers in RELATION TO NeEDLE STICK INJURY

\begin{tabular}{||l|c|c|c|c|c|c|c||}
\hline \multirow{2}{*}{$\begin{array}{l}\text { TRANSMISSION } \\
\text { FACTOR }\end{array}$} & \multicolumn{2}{|c|}{$\begin{array}{c}\text { TOTAL } \\
\text { (N=645) }\end{array}$} & \multicolumn{2}{|c|}{$\begin{array}{c}\text { HIGH RISK INJURIES } \\
\text { (N=187) }\end{array}$} & \multirow{2}{*}{ OR } & P \\
\cline { 2 - 7 } prevalence & VALUE \\
\hline $\begin{array}{l}\text { A Procedure involving a } \\
\text { needle placed directly in } \\
\text { patient's vein or artery }\end{array}$ & 130 & 20.2 & 70 & 53.8 & $50.0 .2-99.6$ & 9.07 & 0.013 \\
\hline $\begin{array}{l}\text { Exposure to a source } \\
\text { patient had evidence of } \\
\text { blood borne infection }\end{array}$ & 36 & 5.6 & 30 & 83.3 & $82.7-99.4$ & 12.36 & 0.003 \\
\hline $\begin{array}{l}\text { Immune status of health } \\
\text { care worker (HBV un- } \\
\text { vaccinated) }\end{array}$ & 83 & 12.9 & 83 & 100.0 & $87.2-100.0$ & 6.35 & 0.000 \\
\hline $\begin{array}{l}\text { A device visibly } \\
\text { contaminated with the } \\
\text { source patient's blood }\end{array}$ & 318 & 49.3 & 195 & 61.3 & $59.1-97.0$ & 1.77 & 0.053 \\
\hline $\begin{array}{l}\text { Depth of the injury } \\
\text { (deep) }\end{array}$ & 133 & 20.6 & 120 & 90.2 & $88.5-100.0$ & 6.60 & 0.000 \\
\hline $\begin{array}{l}\text { The device is large } \\
\text { gauge hollow-bore } \\
\text { needle }\end{array}$ & 236 & 36.6 & 104 & 44.1 & $40.8-65.8$ & 1.59 & 0.305 \\
\hline $\begin{array}{l}\text { Long duration of } \\
\text { potential contact }\end{array}$ & 101 & 15.7 & 53 & 52.5 & $67.7-88.0$ & 1.30 & 0.137 \\
\hline $\begin{array}{l}\text { Body part injured } \\
\text { (Vascular) }\end{array}$ & 102 & 15.8 & 20 & 19.6 & $18.4-72.9$ & 2.62 & 0.309 \\
\hline $\begin{array}{l}\text { Time interval between } \\
\text { injury and wound } \\
\text { cleansing (> 30 minutes) }\end{array}$ & 201 & 31.2 & 70 & 34.8 & $38.7-78.5$ & 1.39 & 0.326 \\
\hline $\begin{array}{l}\text { No personal protective } \\
\text { equipment worn by the } \\
\text { worker }\end{array}$ & 152 & 23.6 & 130 & 85.5 & $78.0-99.9$ & 5.20 & 0.001 \\
\hline $\begin{array}{l}\text { Unavailable and non-use } \\
\text { of prophylactic } \\
\text { medication \# }\end{array}$ & 118 & 18.3 & 45 & 38.1 & $30.9-92.8$ & 1.53 & 0.396 \\
\hline $\begin{array}{l}\text { No follow up testing for } \\
\text { the exposed HCWs }\end{array}$ & 119 & 18.4 & 49 & 41.2 & $32.2-88.5$ & 1.72 & 0.254 \\
\hline \hline
\end{tabular}

$\sim$ (Gloves, mask, eye protection, face shield, gowns)

\# (Anti-retroviral therapy- Immunoglobulin and vaccination for hepatitis B)

* $P$ value is significant at $<0.05$ level 


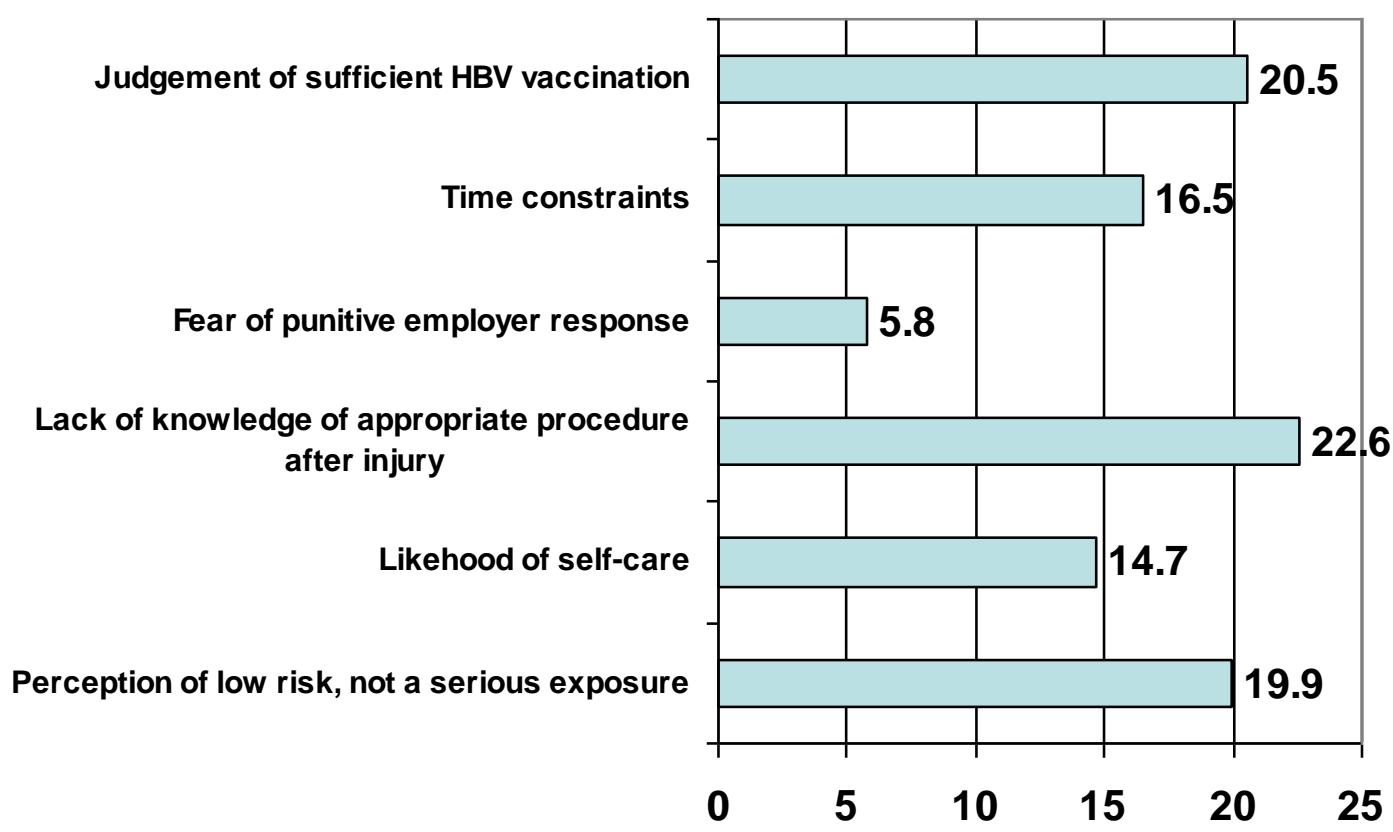

FIGURE 3: POSSIBLE REASONS FOR UNDER-REPORTING AMONG HEALTH CARE WORKERS EXPERIENCING NSIS ( $\mathrm{N}=327)$ 
Table 5: Effectiveness of Existing Measures to prevent NSIs among Health Care WORKERS IN TEACHING HOSPITALS.

\begin{tabular}{|c|c|c|c|c|c|c|}
\hline \multirow[t]{2}{*}{ CONTROL MEASURE } & \multicolumn{2}{|c|}{$\begin{array}{c}\text { NSIS } \\
(\mathrm{N}-438)\end{array}$} & \multicolumn{2}{|c|}{$\begin{array}{l}\text { NO NSIS } \\
(\mathrm{N}=207)\end{array}$} & \multirow[t]{2}{*}{ OR } & \multirow[t]{2}{*}{$95 \% \mathrm{Cl}$} \\
\hline & No. & $\%$ & No. & $\%$ & & \\
\hline $\begin{array}{l}\text { Available and access to safety engineered devices } \\
\text { (sheath or retract after use) }\end{array}$ & 61 & 13.9 & 71 & 34.3 & 0.41 & $0.21-0.73$ \\
\hline $\begin{array}{l}\begin{array}{l}\text { Available and access to personal protective } \\
\text { equipment }\end{array} \\
\end{array}$ & 143 & 32.6 & 86 & 41.5 & 0.82 & $0.43-1.04$ \\
\hline Disposable containers & & & & & & \\
\hline Location (in close proximity to work area) & 124 & 28.3 & 62 & 30.0 & 0.92 & $0.45-1.52$ \\
\hline Rigidity (impermeable plastic box) & 255 & 58.2 & 102 & 49.3 & 0.75 & $0.38-1.94$ \\
\hline Box design (open top) & 279 & 63.7 & 143 & 69.0 & 0.93 & $0.12-2.93$ \\
\hline Awareness of universal precaution guidelines & 283 & 64.6 & 139 & 67.1 & 0.90 & $0.46-1.53$ \\
\hline $\begin{array}{l}\text { Satisfactory adherence of HCW with infection control } \\
\text { guidelines }\end{array}$ & 127 & 29.0 & 123 & 59.4 & 0.42 & $0.26-0.71$ \\
\hline $\begin{array}{l}\text { Training in injection safety, and appropriate work } \\
\text { practices }\end{array}$ & 35 & 8.0 & 56 & 27.0 & 0.14 & $0.03-0.40$ \\
\hline Full immunization against hepatitis $\mathrm{B}$ & 132 & 30.1 & 68 & 32.9 & 0.83 & $0.49-2.74$ \\
\hline Double gloving practice & 28 & 6.4 & 28 & 13.5 & 0.43 & $0.05-1.52$ \\
\hline Organized shift schedule & 126 & 28.7 & 66 & 31.9 & 0.84 & $0.38-1.74$ \\
\hline Sufficient staff number & 259 & 59.1 & 133 & 64.3 & 0.74 & $0.36-2.03$ \\
\hline Work environment characteristics & & & & & & \\
\hline Lighting (bright) & 307 & 70.1 & 156 & 75.4 & 0.83 & $0.53-2.54$ \\
\hline Noise (silence) & 134 & 30.6 & 124 & 59.9 & 0.34 & $0.02-0.71$ \\
\hline Number of people at the bedside (only one) & 192 & 43.8 & 97 & 46.9 & 0.91 & $0.48-2.96$ \\
\hline Condition of hand (dry) & 279 & 63.7 & 150 & 72.5 & 0.74 & $0.18-0.19$ \\
\hline Visibility (good) & 306 & 69.9 & 145 & 70.0 & 0.95 & $0.63-2.83$ \\
\hline Floor condition (clean) & 195 & 44.5 & 98 & 47.3 & 0.78 & $0.26-1.95$ \\
\hline Room temperature (Comfortable) & 177 & 40.4 & 150 & 72.5 & 0.32 & $0.06-0.67$ \\
\hline Periodic in-service health monitoring & 30 & 6.8 & 19 & 9.2 & 0.68 & $0.38-1.05$ \\
\hline Available written protocol for prompt reporting of NSIs & 42 & 9.6 & 80 & 38.6 & 0.37 & $0.02-0.57$ \\
\hline
\end{tabular}

Table 6: Predictors of standard Precautions Practice Score among Health Care WORKERS IN TEACHING HOSPITALS IN ALEXANDRIA

\begin{tabular}{|c|c|c|c|c|c|c|c|c|}
\hline \multirow[b]{2}{*}{ Variables } & \multicolumn{4}{|c|}{ Univariable models } & \multicolumn{4}{|c|}{ Multivariable model $^{\mathrm{a}}$} \\
\hline & B & $\mathrm{F}$ & $P$ & $\mathrm{R}^{2}$ & $\operatorname{ad} \beta$ & $\mathrm{F}$ & $P$ & $\begin{array}{l}95 \% \mathrm{Cl} \\
\text { of } \beta\end{array}$ \\
\hline Knowledge score & 0.22 & 14.39 & 0.000 & 0.06 & 0.18 & 3.05 & 0.003 & $0.06-0.29$ \\
\hline $\begin{array}{l}\text { Perceived susceptibility of } \\
\text { acquiring infection at workplace }\end{array}$ & 0.02 & 0.02 & 0.885 & 0.00 & & & & \\
\hline $\begin{array}{l}\text { Perceived Severity of disease } \\
\text { after NSI }\end{array}$ & 0.35 & 11.83 & 0.001 & 0.05 & & & & \\
\hline Age & 0.05 & 16.29 & 0.000 & 0.07 & & & & \\
\hline Years of work experience & 0.07 & 16.84 & 0.000 & 0.07 & 0.06 & 3.39 & 0.001 & $0.02-0.09$ \\
\hline Occupational group & & 4.00 & 0.008 & 0.04 & & & & \\
\hline Nurse & 1.75 & 2.33 & 0.021 & & & & & \\
\hline Physician & 0.57 & 0.70 & 0.486 & & & & & \\
\hline $\begin{array}{l}\text { Residents, attending surgeons, } \\
\text { training physician, interns }\end{array}$ & 0.62 & 0.89 & 0.375 & & & & & \\
\hline Supportive personnel & 0.98 & 3.14 & 0.002 & & & & & \\
\hline
\end{tabular}




\section{REFERENCES}

1. Kane A, Lloyd J, Zaffran M, Simonsen $\mathrm{L}$, Kane M. Transmission of hepatitis $B$, hepatitis $C$ and human immunodeficiency viruses through unsafe injections in the developing world: model-based regional estimates. Bull World Health Organ. 1999;77(10):801-7.

2. Prüss-Üstün $A$, Rapiti $E$, Hutin $Y$. Sharps injuries: global burden of disease from sharps injuries to healthcare workers. Geneva: World Health Organization; (WHO Environmental Burden of Disease Series No. 3) 2003.

3. World Health Organization. WHO Statistical Information System WHOSIS. Available drom: (accessed at http://wwwnt.who.int/whosis/statistics/menu.cfm, November 2002).

4. Centers for Disease Control and Prevention (CDC). Surveillance of health care workers with HIV/AIDS. Centers for Disease Control, Atlanta, 1998. (accessed November 2002. Available from: http://www.aegis.com/files/cdc/FactSh eets/1998/HCW.pdf).

5. Luthi JC, Dubois-Arber $F$, Iten $A$, Maziero A, Colombo C, Jost J, et al. The occurrence of percutaneous injuries to health-care workers: a cross sectional survey in seven Swiss hospitals. Journal Suisse de Médecine.1998; 128(14):536-43.

6. Talaat M, Kandeel A, El-Shoubary W, Bodenschatz C, Khairy I, Oun S, et al. Occupational exposure to needlestick injuries and hepatitis $B$ vaccination coverage among health care workers in Egypt. American Journal of Infection Control. 2003; 31(8):469-74.

7. Ismail NA, Aboul Ftouh AM, ElShoubary WH. Safe injection practice among health care workers, Gharbiya,
Egypt. J Egypt Public Health Assoc. 2005;80(5-6):563-83.

8. Simonsen L, Kane A, Lloyd J, Zaffran $M$, Kane $M$. Unsafe injections in the developing world and transmission of blood borne pathogens: a review. Bull World Health Organ. 1999;77(10):789800.

9. Abdel-Haleem M. Injection safety: knowledge and practice among health workers of teaching hospitals. MS thesis, Faculty of medicine, Alexandria University, Alexandria, 2004.

10. Tandberg D, Stewart KK, Doezema D. Under-reporting of contaminated needlestick injuries in emergency health care workers. Annals of emergency Medicine. 2005; 20(1):6670.

11. Occupational Safety and Health Administration (OSHA). Needlesticks/Sharps Injuries. Retrieved April 1, 2006. Available from:

http://www.osha.gov/SLTC/etools/hos pital/hazards/sharps/sharps.html.

12. Centers for Disease Control and Prevention (CDC). Workbook for designing, implementing and evaluating a sharps injury prevention program 2004. Retrieved March 31, 2006. Available from: http://www.cdc.gov/sharpssafety/index html.

13. Glanz K, Marcus Lewis F, Rimer BK: Theory at a Glance: A guide for health promotion practice. Second edition. US: National Cancer Institute, National Institute of Health; 2005.

14. Ng YW, Hassim IN. Needlestick injury among medical personnel in Accident and Emergency Department of two teaching hospitals. Med J Malaysia. 2007 Mar;62(1):9-12.

15. Ministry of Health, Department of Therapy, Vietnam. Report on the 
implementation of the APW of a pilot survey on unsafe injection practice in Vietnam, Hanoi: 2003,p. 30.

16. Mingoli A, Sapienza P, Sgarzini G, Modini C. Surgeons' risk awareness and behavioral methods of protection against blood borne pathogen transmission during surgery. Ann Surg. 1999;230:737-8.

17. Trim JC, Elliott TS. A review of sharps injuries and preventative strategies. $J$ Hosp Infect. 2003; 53 (4):237-42.

18. Lee JM, Botteman MF, Xanthakos N, Nicklasson L. Needlestick injuries in the United States. Epidemiologic, economic, and quality of life issues. AAOHN J. 2005;53 (3):117-33.

19. Lewis FR, Short LJ, Howard RJ, Jacobs AJ, Roche NE. Epidemiology of injuries by needles and other sharp instruments. Minimizing sharp injuries in gynecologic and obstetric operations. Surg. Clin. North Am. 1995;75 (6):1105-21.

20. Ippolito G, Puro V, Petrosillo N, et al. (1997). Prevention, Management and Chemoprophylaxis of Occupational Exposure to HIV. US: International Health Care Worker Safety Center, University of Virginia; 1997. 15-16 \& 26-30.

21. Sohn S, Eagan J, Sepkowitz KA, Zuccott G. Effect of implementing safety engineered devices on percutaneous injury epidemiology. Infect. Control Hosp. Epidemiol. 2004; 25 (7):536-42.

22. Shiao, JSC, Chuang YC, Ko WC, Huang KY, Guo YL. The prevalence of needlestick and sharp object injuries at a medical center in Taiwan. Nosocomial. Inf Conl J. 1997;4:20714.

23. Bsn SQW, Eljkemans G. Preventing Needlestick Injuries among Healthcare Workers: A WHO-ICN Collaboration.
INT J OCCUP ENVIRON HEALTH. 2004;10:451-6.

24. Guo YL, Shiao J, Chuang YC, Huang KY. Needlestick and sharps injuries among health-care workers in Taiwan. Epidemiol Infect. 2000;122(2):259-65.

25. Occupational Safety and Health Administration: Final rule on occupational exposure to blood borne pathogens. 56 Fed Reg. 64004 (1991).

26. Shiao J. Estimation of the risk of blood borne pathogens to health care workers after a needlestick injury in Taiwan. American Journal of Infection Control. 2002; 30: 15-20.

27. Centers for Disease Control and Prevention. Immunization of healthcare workers: recommendations of the Advisory Committee on Immunization Practices (ACIP) and the Hospital Infections Control Practices Advisory Committee (HICPAC). Morbid. Mortal. Weekly Rep. 1997;46(RR-18):23.

28. Puro V. Risk of exposure to blood borne infection for Italian healthcare workers, by job category and work area. Infection Control and Hospital Epidemiology. 2001; 22: 206-10.

29. Sulkowski MS, et al. Needlestick transmission of hepatitis C. JAMA. 2002;287: 406-13.

30. Beltrami EM, Williams IT, Shapiro CN, Chamberland ME. Risk and Management of Blood-Borne Infections in Health Care Workers. Clinical Microbiology Reviews. 2000;13 (3):385-407.

31. Abu-Gad HA, Al-Turki KA. Some epidemiological aspects of needle stick injuries among the hospital health care workers: Eastern province, Saudi Arabia. European Journal of Epidemiology. 2001; 17: 401-7.

32. Centers for Disease Control and Prevention. National Institute for Occupational Safety and Health 
$(\mathrm{NIOSH}) \mathrm{NIOSH}$ Alert: Preventing Needlestick Injuries in Health Care Settings, 1999. Publication No. 2000108.

33. Yassi A, McGill ML, Khokhar JB. Efficacy and cost effectiveness of a needleless intravenous access system. Am J infect Control. 1995;23:57-64.

34. WHO. Sharp injuries, Health care worker safety. Protection of the human environment. Environmental burden of disease. Series No.11 Geneva, 2005, Annex 2.

35. Centers for Disease Control. Perspective in disease prevention and
36. health promotion update. Standard precautions for prevention of transmission of HIV, HBV and other blood-borne pathogens in health care settings. MMWR1. 988;37:24.

37. Henry K, Campbell S, Collier P, Williams CO. Compliance with standard precautions and needle handling and disposal practices among emergency department staff at two teaching hospitals. Am J Infect Control. 1994, 22(3):129-37.

38. Michalsen A, Delclos GL, Felknor SA, Davidson AL, Johnson PC, Vesley D, et al. Compliance with standard precautions among physicians. J Occup Environ Med.1997, 39(2):1307. 